DOI https://doi.org/10.18551/rjoas.2018-06.16

\title{
ANALYSIS OF SUITABILITY AND CARRYING CAPACITY OF TOURISM IN TIDUNG ISLAND, KEPULAUAN SERIBU, INDONESIA
}

\author{
Simanjuntak Susi Watina* \\ Coastal Resource Management, Faculty of Fisheries and Marine Sciences, \\ Diponegoro University of Semarang, Indonesia \\ Supriharyono, Haeruddin \\ Master's Degree Program in Beach Resource Management, \\ Diponegoro University of Semarang, Indonesia \\ *E-mail: susiwatina@gmail.com
}

\begin{abstract}
Tidung Island has the potential for the development of marine tourism area. Since 2009, the number of tourists visiting the area has been increasing every year. Without proper management, however, this condition might harm the surrounding ecosystem. This study aims to determine the suitability and carrying capacity of coastal tourism area in Tidung Island, Kepulauan Seribu. This study used the analyses of coastal tourism suitability index and carrying capacity of coastal area. The results showed the suitability index of the research locations was $94.05 \%$ with the carrying capacity of 180 tourists per day for the first location; the second location was $89.28 \%$ with the carrying capacity of 300 tourists per day; and for the third location was $94.05 \%$ with the carrying capacity of 60 tourists per day. The three research sites are categorized into very suitable in terms of the suitability as tourism spots.
\end{abstract}

\section{KEY WORDS}

Coastal tourism, site suitability, carrying capacity, ecology, Tidung Island.

Tidung Island is one member of the cluster of islands in the district of South Kepulauan Seribu, Jakarta, Indonesia. The Regional Regulation of Jakarta (2012) article 171 has established greater Tidung Island as a residential area, not as a tourism area. However, some regulations permit tourism activities on the residential islands as well. One of them is stated in article 172 that writes "to support the realization of residential area as fisherman's tourism area as a tourism destination object may build homestays and/or lodgings, as well as people's business centers including service centers of tourism".

The tourism activities in Tidung Island particularly are managed by community-based tourism concept (Statistic Bureau, Kepulauan Seribu, 2016). Tidung Island involves the community to develop the tourism sector while the position of the government is as the supervisor (Khrisnamurti et al., 2016). The area has underwater and coastal beauties and panorama as the main reason for tourists to have tourism activities such as: playing sand, swimming, fishing, snorkeling, diving, water sports (banana boat, jet skiing, and canoeing), photography, and beach walking, camping and other activities. The tourism activities encourage business opportunities for the community in order to improve the economy (Statistic Bureau, Kepulauan Seribu, 2016).

The tourism activities in Tidung Island have started since 2009, and the number of tourists or visitors has shown positive trend every year. Graphic on tourist visits from 2011 to 2017 is as follows: 


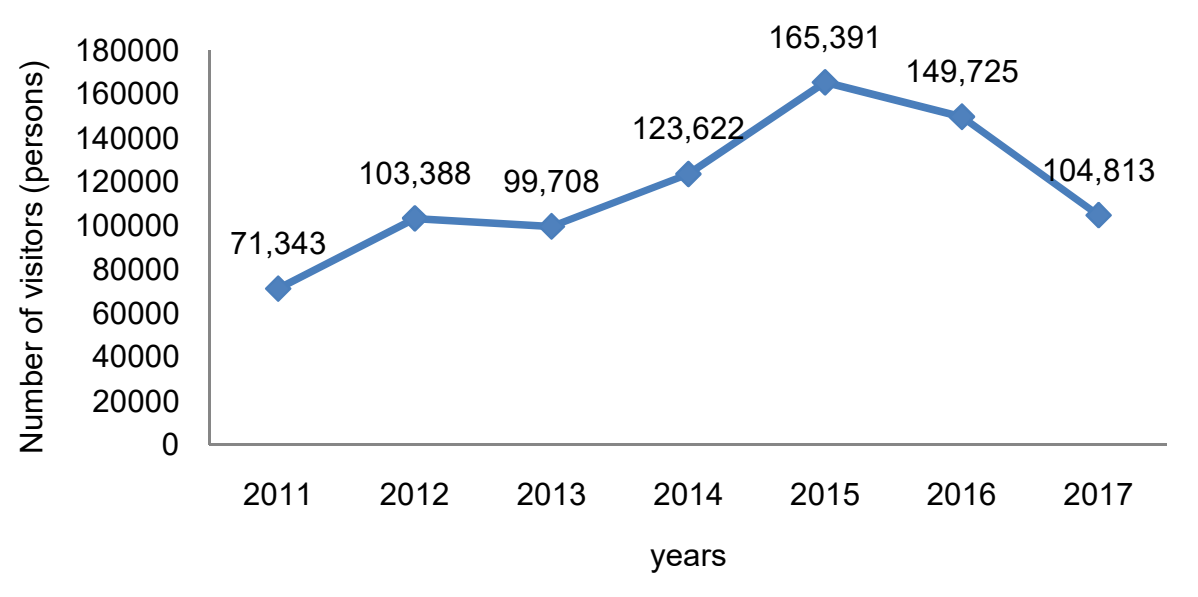

Source: Annual report of Village Government of Tidung Island in 2017

Figure 1 - Graphic of tourist visits in Tidung Island in 2011-2017

The increasing number of tourist's visits every year, on the other hand, has caused some declines on the environmental quality, and it is predicted to have negative impacts on the tourism sustainability in Tidung Island area (Khrisnamurti et al., 2016). In addition to impact on the aquatic environment, the comfort level of the tourists also decreased so that became the reason for the decreasing number of tourists in 2016-2017 as shown in Figure 1. Based on interviews with local tourism management in Tidung Island, the number of tourists visiting the location often exceeds the availability of facilities that tourists need, such as lodging and ATM.

Supriharyono (2016) stated that the increasing number of tourist visits in the Kepulauan Seribu, including the Tidung Island and surrounding areas with those all activities, may cause some pressures on the environmental destruction, and the damage to coral reefs in particular might be even greater. The carrying capacity of the area is needed to accommodate the tourists and keep the tourism activities from inflicting damage; the tourism site can be preserved as well as sustainable (Yulianda, 2007).

The purpose of this study is to determine the suitability of coastal tourism and the carrying capacity of tourism areas in Tidung Island. This research is expected to overcome the emerging issues in Tidung Island.

\section{METHODS OF RESEARCH}

This research was conducted in three coastal tourism locations, namely Jembatan Cinta beach, Cemara Kasih beach, and Surga beach. Site location was chosen purposively by considering the number of tourist visits in crowded, medium, and quiet tourism locations. Data collection was conducted in February 2018.

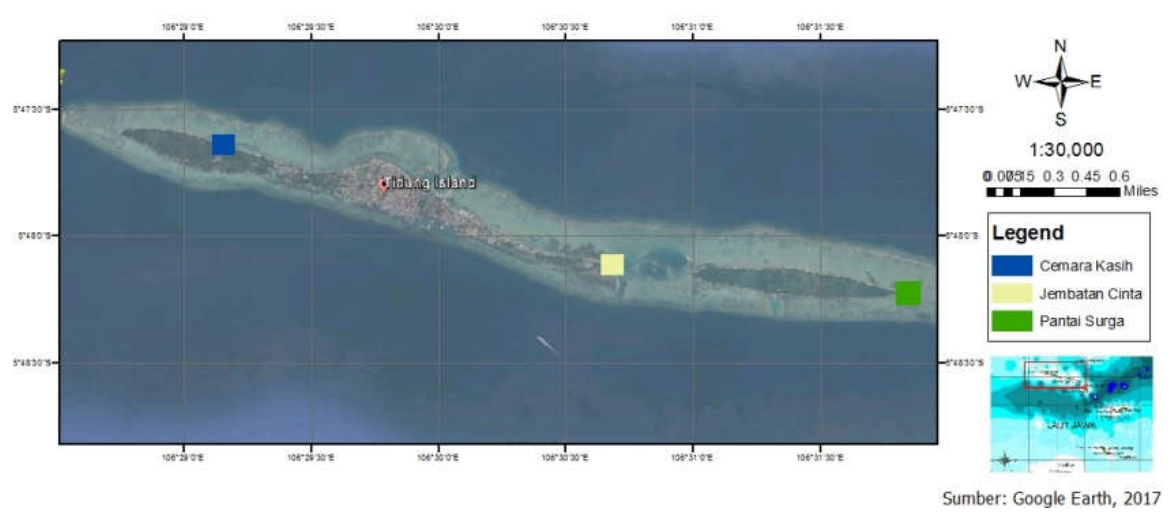

Figure 2 - Research location in Tidung Island 
Observation was conducted to obtain the data related to tourism suitability parameters, and it was conducted through direct on-site observation as well as recording systematically to any events that appeared on the research sites (Prastowo, 2010). In addition, interviews were also conducted to investigate the perspectives of the relevant stakeholders in particular field (Alshenqeeti, 2014), namely tourism managements, communities and tourists/visitors in order to determine the carrying capacity of the area.

The determination of the tourism suitability index of coastal tourism category refers to Yulianda (2007) as follows:

Table 1 - Matrix of site suitability for tourism activities

\begin{tabular}{|c|c|c|c|c|c|c|c|c|c|c|c|}
\hline \multirow[b]{2}{*}{ ref. } & \multirow[b]{2}{*}{ Parameters } & \multirow[b]{2}{*}{ 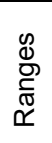 } & \multicolumn{8}{|c|}{ Categories and scores } & \multirow[b]{2}{*}{$\mathrm{N}_{\max }$} \\
\hline & & & S1 & 号 & S2 & 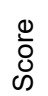 & s3 & $\begin{array}{l}0 \\
0 \\
0\end{array}$ & TS & $\begin{array}{l}0 \\
\stackrel{0}{0} \\
心\end{array}$ & \\
\hline 1. & Water depth (m) & 5 & $0-3$ & 3 & $>3-6$ & 2 & $>6-10$ & 1 & $>10$ & 0 & 15 \\
\hline 2. & Beach types & 5 & White sand & 3 & $\begin{array}{l}\text { White sand } \\
\text { with some } \\
\text { reefs }\end{array}$ & 2 & $\begin{array}{l}\text { Black sand, } \\
\text { some rocky } \\
\text { reefs }\end{array}$ & 1 & Mud, rocks & 0 & 15 \\
\hline 3. & Width of beach $(\mathrm{m})$ & 5 & $>15$ & 3 & $10-15$ & 2 & $3-<10$ & 1 & $<3$ & 0 & 15 \\
\hline 4. & $\begin{array}{l}\text { Waters basic } \\
\text { material }\end{array}$ & 3 & Sand & 3 & Sandy reefs & 2 & Muddy sand & 1 & Mud & 0 & 9 \\
\hline 5. & Waves (m/s) & 3 & $0-0.17$ & 3 & $0.17-0.34$ & 2 & $0.34-0.51$ & 1 & $>0.51$ & 0 & 9 \\
\hline 6. & Beach slope $\left(^{\circ}\right)$ & 3 & $<10$ & 3 & $10-25$ & 2 & $>25-45$ & 1 & $>45$ & 0 & 9 \\
\hline 7. & $\begin{array}{l}\text { Water brightness } \\
(\%)\end{array}$ & 1 & $80-100$ & 3 & $50-<80$ & 2 & $20-<50$ & 1 & $<20$ & 0 & 3 \\
\hline 8. & $\begin{array}{l}\text { Coastal areal } \\
\text { coverage and } \\
\text { shades }\end{array}$ & 1 & $\begin{array}{l}\text { Coconut } \\
\text { trees, open } \\
\text { space }\end{array}$ & 3 & $\begin{array}{l}\text { Bushes } \\
\text { (low-tall), } \\
\text { savanna }\end{array}$ & 2 & Tall bushes & 1 & $\begin{array}{l}\text { Mangrove } \\
\text { forest, } \\
\text { residential area }\end{array}$ & 0 & 3 \\
\hline 9. & Dangerous biota & 1 & None & 3 & swine & 2 & $\begin{array}{l}\text { swine, } \\
\text { stingrays }\end{array}$ & 1 & $\begin{array}{l}\text { Swine, } \\
\text { stingrays, } \\
\text { stonefish, } \\
\text { sharks }\end{array}$ & 0 & 3 \\
\hline 10. & $\begin{array}{l}\text { Freshwater } \\
\text { availability (km) }\end{array}$ & 1 & $<0.5$ & 3 & $>0.5-1$ & 2 & $>1-2$ & 1 & $>2$ & 0 & 3 \\
\hline
\end{tabular}

Source: Yulianda (2007)

Information: Ni $\max =84$

Tourism suitability index (TSI) of coastal tourism is formulated as follows (Yulianda, 2007):

$$
\mathrm{TSI}=\frac{\Sigma \mathrm{Ni}}{\Sigma \mathrm{Nmax}} \times 100 \%
$$

Where: $\mathrm{TSI}=$ tourism suitability index (\%); $\mathrm{Ni}=$ score for each affecting factor; $\mathrm{N}_{\max }=$ maximum score for tourism activities.

The results of the calculations are classified into four classes of suitability, as follows:

Table 2 - Classifications of categories for tourism suitability of coastal tourism

\begin{tabular}{ll}
\hline Categories & Score \\
\hline Very appropriate (S1) & $83-100 \%$ \\
Appropriate (S2) & $50-<83 \%$ \\
Conditional appropriate (S3) & $17-<50 \%$ \\
Not appropriate & $<17 \%$ \\
\hline
\end{tabular}

Source: Yulianda (2007).

If the location of coastal tourism is in the appropriate category (very appropriate, appropriate, and conditional), the calculation of carrying capacity of the area (CCA) should be measured. The calculation is intended to reduce the impact of over-capacity in tourist sites. The carrying capacity of the area is determined by the formula proposed Yulianda (2007) as follows:

$$
\mathrm{CCA}=\mathrm{K} \times \frac{\mathrm{Lp}}{\mathrm{Lt}} \times \frac{\mathrm{Wt}}{\mathrm{Wp}}
$$


Where: $\mathrm{CCA}=$ carrying capacity of the area; $\mathrm{K}=$ maximum visitors per unit of area; $\mathrm{Lp}=$ area or length of area that can be utilized; $\mathrm{Lt}=$ unit area for a particular category; $\mathrm{Wt}=$ Time provided by the region for tourism activities in one day; $\mathrm{Wp}=$ time spent by visitors for certain activities.

The visitor's ecological potential $(K)$ is determined based on the condition of the resource and types of activities to be developed. The length and width of territory that visitors can use is considered with the natural ability to tolerate the visitor's disruptive preservation. Tourism provisions based on the ecological potential, area and time of visitors at the tourism attractions are presented in the following table.

Table 3 - Coastal tourist requirements based on ecological potential, width and prediction of time

\begin{tabular}{llllll}
\hline Types of activities & $\Sigma$ visitors $(\mathrm{K})$ & Area unit $(\mathrm{Lt})$ & Time $(\mathrm{Wt})$ & Visitor's time $(\mathrm{Wp})$ & Description \\
\hline Snorkeling & 1 & $500 \mathrm{~m}^{2}$ & 6 & 3 & Every 1 visitor in $100 \times 5 \mathrm{~m}$ \\
Coastal beaches & 1 & $50 \mathrm{~m}$ & 6 & 3 & 1 visitor in every $50 \mathrm{~m}$ coastal line \\
Water sports activities & 1 & $50 \mathrm{~m}$ & 4 & 2 & 1 visitor in every $50 \mathrm{~m}$ coastal line \\
Swimming & 1 & $50 \mathrm{~m}$ & 4 & 2 & 1 visitor in every $50 \mathrm{~m}$ coastal line \\
Sunbathing & 1 & $50 \mathrm{~m}$ & 4 & 2 & 1 visitor in every $50 \mathrm{~m}$ coastal line \\
Fishing & 1 & $10 \mathrm{~m}$ & 6 & 3 & 1 visitor in every $50 \mathrm{~m}$ coastal line \\
Camping area & 5 & $100 \mathrm{~m}^{2}$ & 24 & 24 & 5 visitors in every $100 \mathrm{~m}^{2}$ \\
\hline
\end{tabular}

Source: modified from Yulianda (2007).

The duration that the region provides for tourism activities at each location is different. The time the visitors spend on the tourism activities was obtained through interviews.

\section{RESULTS AND DISCUSSION}

General condition of research location. Tidung Island village is one of three villages in the District of South Kepulauan Seribu. Geographically, the northern boundary lies at $5^{\circ} 46^{\prime} 15^{\prime \prime} \mathrm{SL}$, southern boundary of $106^{\circ} 34^{\prime} 22^{\prime \prime} \mathrm{EL}$, eastern boundary of $5^{\circ} 59^{\prime} 30^{\prime \prime} \mathrm{EL}$, and western boundary of $106^{\circ} 26^{\prime} 00^{\prime \prime}$ EL. The total area of Tidung Island is $106.19 \mathrm{Ha}$ with the height of 1 meter from the sea level (Tidung Island Village, 2018).

According to the information obtained from the village government of Tidung Island (2017), the population of Tidung Island is about 5,000 people, and the majority is fishermen and seaweed farmers. Based on interviews with the local community, there was a failure of seaweed crops due to the disease that attacked almost all the area in Kepulauan Seribu. For this matter, people began to open business opportunities in the field of tourism to boost their economy. There are some alternative businesses for the community such as opening rental services for snorkeling equipment, banana boat, bicycle, tour guide, catering business, food stalls, homestays, and boat rental. People claim that their economy has increased since the opening of this tourism area. This is in line that the potential for economic development of the tourism sector is determined by the nature of the environment and the structured management (Bunghez, 2016).

Tidung Island has tourism potential and attraction which can be developed. The waters of Tidung Island, for instance, are categorized into shallow waters with the water depth of $<3 \mathrm{~m}$ from the coastline up to a distance of $\pm 200 \mathrm{~m}$ towards the sea. The current velocity of the waters is relatively weak because of the naturally occurring wave holder from the pile of broken corals. Generally this beach has white and smooth sand. There is also a museum of shark skeletons built by the Sub-Agency of Marine and Fisheries Affairs of Provincial Government of Jakarta on the Tidung Kecil Island; these potentials are very suitable as tourism attractions in this area.

The government and the community give positive attitudes towards the development of tourism on Tidung Island as it is indicated from the role of government that provides better facilities, accessibility, as well as services for the convenience of the tourists. One of the government's supports is the assigninment of some janitors on Tidung Island, doing counseling to the public for the improvement of human resources in the field of tourism, constructing and repairing the roads for better access, and so forth. Tidung village (2018) 
has stated that the implementation of coaching and mentorship to smaller economic entrepreneurs is continuously improved, either through training in improving product quality as well as providing capital loan for the sustainability of their businesses. Sub-Agency of Tourism and Culture of Provincial Government of Jakarta also has plans for the construction of more adequate facilities in the tourist area near Jembatan Cinta. In terms of social acceptance, the community is very pleased to welcome the tourism activities in Tidung Island as it can be seen from the enthusiasm of the community in providing services for the tourists, including lodgings, restaurants, and other tourists' needs.

From the social point of view, both community and government are very supportive of tourism activities. However, in terms of ecology, the increasing number of tourists has the potential to increase the pressure of environmental damage of the water, especially coral reefs. Research location found some coral fractures which have been allegedly trampled by tourists. There are also some food wrappers made of plastics in the waters. According to one of the tour managements, the trash (in the water) mainly comes from tourists who feed the fish in the area of snorkeling spots, indicating that the awareness of the tourists in preserving the aquatic ecosystems is still lacking. Based on research conducted by Supriharyono (2016), coral reefs in Tidung Island are generally damaged due to sediment from tourism activities, especially in the area of reef flats or shallow areas $( \pm 1 \mathrm{~m})$, while in deep waters or reef edge / reef slope areas (5-6 m), the condition of the coral reefs tend to be quite preserved.

Tourism activities greatly affect the condition of the waters. If they are not managed properly, the activities threaten the ecosystem causing the sustainability may not run well. All relevant parties, communities, governments and tourists need to jointly protect the environment in the area of tourism spots. Based on interviews with the staffs of the village government, to anticipate the peak season, the government is planning to set the limit number of visits, but this has not yet been implemented. The Regional Government also has training programs for tour guides, snorkeling, diving, and food-processing training for the typical culinary of Tidung Island.

Tourism Suitability Index for coastal tourism of Tidung Island. The tourism suitability is a criterion of resources and environment to meet the needs of tourism development. The measurement of tourism suitability index in the study sites is presented in Table 4.

Table 4 - Score of tourism suitability index for coastal tourism of Tidung Island

\begin{tabular}{|c|c|c|c|c|c|c|c|c|c|c|c|c|}
\hline Ref. & Parameters & Ranges & $\begin{array}{l}\text { Jembatan } \\
\text { Cinta Bridge }\end{array}$ & Score & $\mathrm{N}_{\mathrm{i}}$ & $\begin{array}{l}\text { Cemara } \\
\text { Kasih } \\
\text { Beach }\end{array}$ & Score & $\mathrm{N}_{\mathrm{i}}$ & $\begin{array}{l}\text { Surga } \\
\text { Beach, } \\
\text { Tidung } \\
\text { Kecil }\end{array}$ & Score & $\mathrm{N}_{\mathrm{i}}$ & $\mathrm{N}_{\max }$ \\
\hline & & $a$ & $\mathrm{~b}$ & $\mathrm{C}$ & $a \times c$ & $\mathrm{~B}$ & $\mathrm{C}$ & $a \times c$ & $\mathrm{~b}$ & $\mathrm{C}$ & $a \times c$ & $a \times 3$ \\
\hline 1. & $\begin{array}{l}\text { Water depth } \\
\text { (m) }\end{array}$ & 5 & $0.3-1.5$ & 3 & 15 & $0.3-1$ & 3 & 15 & $\begin{array}{l}0.28- \\
0.45\end{array}$ & 3 & 15 & 15 \\
\hline 2. & Beach types & 5 & White sand & 3 & 15 & White sand & 3 & 15 & $\begin{array}{l}\text { White } \\
\text { sand }\end{array}$ & 3 & 15 & 15 \\
\hline 3. & $\begin{array}{l}\text { Width of } \\
\text { beach }(\mathrm{m})\end{array}$ & 5 & 16 & 3 & 15 & 11.35 & 2 & 10 & 48 & 3 & 15 & 15 \\
\hline 4. & $\begin{array}{l}\text { Waters basic } \\
\text { material }\end{array}$ & 3 & Sandy reefs & 2 & 6 & Sandy reefs & 2 & 6 & $\begin{array}{l}\text { Sandy } \\
\text { reefs }\end{array}$ & 2 & 6 & 9 \\
\hline 5. & Waves $(\mathrm{m} / \mathrm{s})$ & 3 & 0.065 & 3 & 9 & 0.042 & 3 & 9 & 0.062 & 3 & 9 & 9 \\
\hline 6. & $\begin{array}{l}\text { Beach slope } \\
\left({ }^{\circ}\right)\end{array}$ & 3 & 1.146 & 3 & 9 & 2.576 & 3 & 9 & 0.258 & 3 & 9 & 9 \\
\hline 7. & $\begin{array}{l}\text { Water } \\
\text { brightness (\%) }\end{array}$ & 1 & 100 & 3 & 3 & 100 & 3 & 3 & 100 & 3 & 3 & 3 \\
\hline 8. & $\begin{array}{l}\text { Coastal areal } \\
\text { coverage and } \\
\text { shades }\end{array}$ & 1 & $\begin{array}{l}\text { Open } \\
\text { space, } \\
\text { coconut } \\
\text { trees, pines }\end{array}$ & 3 & 3 & $\begin{array}{l}\text { Openspace, } \\
\text { coconut } \\
\text { trees }\end{array}$ & 3 & 3 & $\begin{array}{l}\text { Tall } \\
\text { bushes }\end{array}$ & 1 & 1 & 3 \\
\hline 9. & $\begin{array}{l}\text { Dangerous } \\
\text { biota }\end{array}$ & 1 & $\begin{array}{l}\text { Bulu babi, } \\
\text { ikan lepu } \\
\text { (stonefish) }\end{array}$ & 1 & 1 & Stone fish & 2 & 2 & None & 3 & 3 & 3 \\
\hline 10. & $\begin{array}{l}\text { Freshwater } \\
\text { availability } \\
(\mathrm{km})\end{array}$ & 1 & $<0.5$ & 3 & 3 & 0.3 & 3 & 3 & $<0.5$ & 3 & 3 & 3 \\
\hline & \multicolumn{3}{|c|}{$\begin{array}{l}\text { Total }(\Sigma) \\
\text { Tourism Suiatability Index }(\%) \\
\text { Categories }\end{array}$} & $\begin{array}{l}: \\
\vdots\end{array}$ & $\begin{array}{l}79 \\
94.05 \\
\text { S1 }\end{array}$ & & & $\begin{array}{l}75 \\
89.28 \\
\text { S1 }\end{array}$ & & & $\begin{array}{l}79 \\
94.05 \\
\text { S1 }\end{array}$ & 84 \\
\hline
\end{tabular}

Source: processed primary data (2018); Description: $N_{\max }$ for coastal tourism 84. 
Water depth ranges from 0.3-1.5 m measured from the coastline to $200 \mathrm{~m}$ towards the sea. Tourists usually do coastal tourism activities no more than $200 \mathrm{~m}$ distance and not more than $1.5 \mathrm{~m}$ depth as the criteria is considered safe for the tourists visiting the coastal tourism of Tidung Island. Yulisa et al., (2016) stated that the depth of the waters is an important aspect in determining coastal tourism areas especially swimming activities because it is very influential on safety, and physically, shallow waters are more suitable for coastal tourism activities than deeper waters.

The type of the coastal tourism in the research location is beach with white sand. Beaches with white sand are generally more attractive to tourists than black sand, muddy, or rocky ones. The preference is indicated by the level of tourism suitability in doing tourism activities, especially coastal tourism. In addition, the color and type of sand also gives its own aesthetic value for tourists. Yulianda (2007) in the tourism suitability matrix also states that the type of beach with white sand is more suitable for tourism than other beach types.

The width of the beaches on Tidung Island varies. The beach for the research location has 11.35 to $48 \mathrm{~m}$ width. The wider a beach, the better to be a tourism attraction. The width of the beach can be used for the tourists' mobility, such as walking leisurely, sunbathing, documenting, cycling, playing sand and so on (Tambunan et al., 2013).

Basic materials or substrates in the waters on Tidung Island in general are the sand with a few shards of corals carried by the waves. Despite the fact that there are fragments of coral, but these waters are still suitable for the tourism category.

Current conditions in the waters of Tidung Island are quite weak up to a distance of 200 $\mathrm{m}$ from the mainland. Current velocities during the survey in February ranged from 0.042$0.065 \mathrm{~m} / \mathrm{sec}$. Yogaswara et al. (2016) state that currents in the waters of Tidung Island are tidal currents that are affected by wind speed.

The beach slope of the research sites ranges from $0.258^{\circ}$ to $2.576^{\circ}$. This angle is categorized as a flat beach category. The beach slope $<10^{\circ}$ is categorized into the flat beach category, $10^{\circ}-25^{\circ}$ is moderate category, while $>25$ is steep category (Yulianda, 2007).

The results showed the water brightness reaches $100 \%$ because the waters of the Tidung Island is categorized into shallow waters, so the penetration of light can penetrate through the bottom of the waters. According to Wijaya et al., (2018), high brightness may be affected by shallow depths that have been penetrated by the sunlight into the water column. Hasriyanti (2013) similarly states that water transparency can be influenced by depth factor, while Yulisa et al. (2016) stated that the material or substrate of water base is the determinant of the waters' brightness. The brightness values are also influenced by various factors such as microorganisms, suspended solids, weather, measurement time and level of accuracy (Mutmainah et al., 2016).

The coverage of the research sites are open land with several types of trees such as coconut, fir, pandanus odorifer, ketapan, waru trees (Hibiscus tiliaceus), and others. In contrast to the third location, the coverage of the location is bushes because the third location is still in the stage of revamping to be developed into ecosystem-based tourism attractions.

The observation on dangerous biota was conducted to anticipate the occurrence of dangers that may threaten the visitors. The dangerous biota are commonly found in the waters of Tidung Island are swine and stonefish. Swine is usually clustered and visible, so tourists can avoid the dangers from this species, while the stonefish resembles stone occasionally trampled by tourists because it is very difficult to distinguish. It is already anticipated by the provision of health posts around the sites as well as several mobile health centers around. Prevention is also done from the warning and guidance of the tour guides.

The availability of freshwater on Tidung Island is still sufficient with the distance from tourist sites is also relatively close, i.e. no more than $500 \mathrm{~m}$. The availability of fresh water is very important in life, including in tourism activities (Yulisa, 2016).

The three research sites on Tidung Island have varying values and are categorized as very suitable (S1). Water resources in Tidung Island has potential to be developed into tourism destinations, especially coastal tourism. The utilization of tourism potentials should be well managed to maintain ecosystem balance and tourism sustainability. Dahuri et al., 
(2004) state that one of the conditions of sustainable development of an ecologically sound region should be placed in a biophysically appropriate location.

Carrying Capacity of Coastal Tourism Area in Tidung Island. The research locations show that the tourism suitability index is in a very suitable category. For further management, it is necessary to analyze the carrying capacity of the area. According to Putra et al., (2015), the analysis of tourism carrying capacity is to compare the area used by travelers with defined average individual standards with the efficiency of visitation time. Hamzah (2012) states that the carrying capacity of the area is the maximum number of visitors who can physically be accommodated by the area at a certain time without causing disruption to nature as well as to the humans.

The calculation of carrying capacity of the coastal tourism area is presented in the following table.

Table 5 - Carrying capacity of coastal tourism area in Tidung Island

\begin{tabular}{|c|c|c|c|c|c|c|c|}
\hline Ref. & Locations & $\mathrm{K}^{*}$ & Lp & $\mathrm{Lt}^{*}$ & Wt & $W p^{*}$ & CCA \\
\hline 1. & Jembatan Cinta beach & 1 & $3,000 \mathrm{~m}$ & $50 \mathrm{~m}$ & 9 hours & 3 hours & 180 person/day \\
\hline 2. & Cemara Kasih beach & 1 & $5,000 \mathrm{~m}$ & $50 \mathrm{~m}$ & 9 hours & 3 hours & 300 person/day \\
\hline 3. & Pantai Surga beach & 1 & $1,500 \mathrm{~m}$ & $50 \mathrm{~m}$ & 6 hours & 3 hours & 60 person/day \\
\hline
\end{tabular}

Source: *Yulianda (2007).

The tourist's ecology potential is 1 person for every 50 meter long beach, assuming the time the visitor takes is 3 hours in average. The time provided by the tourist area in one day depends on the area management and can be different in each location.

Jembatan Cinta is a link between Tidung Besar Island and Tidung Kecil Island. Jembatan Cinta beach (location I) has an area of $3,000 \mathrm{~m}^{2}$ utilization with the carrying capacity of 180 people/day. Based on the comparison of statistical data in Tidung Island village, location I has already experienced over carrying capacity especially at the peak season such as holiday season. Peak tourist arrivals usually occur on weekends and holidays, while on typical days (weekdays), the number of tourist visits is quite normal.

The accumulation of tourists at the location I is due to the Jembatan Cinta beach is the flagship icon of tourism on Tidung Island, and it has strategic location. For location II, it is supposed to be able to accommodate more tourists than location I. As its location and accessibility in this location is not enough, however, hence number of visitors is not as many location I. Location II experiences over carrying capacity during holiday of festival and New Year's Eve. The improvement of infrastructure especially roads to Cemara Kasih location is necessary. Location III is still empty from visitors, and it is still under development stage. This location can be used as a tourist location with limited utilization and still maintaining the preservation of the ecosystem.

Based on observation, the majority of tourists who visit Tidung Island come from Greater Jakarta area and West Java. The rationale for the visitors is due to close distance from their home to the location, and it can be reached from Kali Adem and Marina Ancol ports for 2-3 hour trip. The demography of the tourists is in general young visitors ranging 1926 years old; mostly they are employers in private sectors and students. In general, tourists come in groups with friends, family, and entourage (managed by travel agent) to reduce costs. During one visit period, the majority of tourists spend 2 days, usually on weekend or holiday. The management should characterize the tourists in order to create sustainable tourism (Zelenka et al., 2014).

The accumulation of tourists during peak season or holidays may affect the availability of their needs during the travels. Logistics needs such as food, water, electricity are still met, but the needs for lodgings or homestays are hard to accommodate. The report by Pulau Tidung (2018) village states that there are 156 homestays on Tidung Island, 97 lodgings, and 45 units of rented houses. For tourism facilities, there are 16 units of banana boats, 2.084 bikes units, and 1,831 units of snorkeling equipment. The available facilities are only to meet the needs of tourists on a typical day, but not during on holidays or peak season, especially 
New Year's Eve. In addition, tourists often complain about the availability of ATM in the location, which is only 1 unit. The provision of facilities affects the tourists' comfort level.

The carrying capacity is different in each tourism location. Even over a period of time and conditions, the carrying capacity of the area may be different even in the same location. Hamzah (2012) states that the carrying capacity of a region is not static (a fixed value), but varies according to the biogeophysical (ecological) conditions of the area as well as the human needs for natural resources and environmental services. Human activities and natural forces such as natural disasters may also degrade the carrying capacity of an area.

\section{CONCLUSION}

The locations utilized for beach tourism attraction in Tidung Island have already met the criteria of the tourism suitability of the area. The value of tourism suitability index of location I and III is $94.05 \%$, while location II is $89.28 \%$. The three research sites show very high suitability index scores and are categorized as very appropriate (S1) sites. The carrying capacity of the area for these three locations is different, e.g. 180 people/day at Jembatan Cinta beach, 300 people/day at Cemara Kasih beach, and 60 people/day at Surga beach. The results show that there is over carrying capacity during peak season, while the number of tourist visits is quite normal on normal days (working days).

\section{REFERENCES}

1. Alshenqeeti, H. 2014. Interviewing as a Data Collection Method: A Critical Review. English Linguistics Research, 3(1):39-45.

2. Badan Pusat Statistik. 2016. Kabupaten Kepulauan Seribu Dalam Angka 2016. BPS Kabupaten Kepulauan Seribu. Kepulauan Seribu.

3. Bunghez, C L. The importance of Tourism to a Destination's Economy. Journal of Eastern Europe Research in Business \& Economics, 2016(2016):1-9.

4. Dahuri R., J Rais, SP Ginting, \& MJ Sitepu. 2004. Pengelolaan Sumberdaya Wilayah Pesisir dan Lautan Secara Terpadu. Jakarta: PT. Pradnya Paramita.

5. Gubernur DKI Jakarta. 2012. Peraturan Daerah (PERDA) Provinsi DKI Jakarta Nomor 1 tahun 2012 tentang Rencana Tata Ruang Wilayah (RTRW) 2030. Sekretariat Negara. Jakarta.

6. Hamzah, 2012. Model Pengelolaan Pencemaran Perairan Pesisir Bagi Keberlanjutan Perikanan dan Wisata Pantai Kota Makasar. Unpublished Dissertation. Sekolah Pascasarjana, Institut Pertanian Bogor, Bogor.

7. Hasriyanti. 2013. Analisis Kelerengan dan Jenis Butir Sedimen Dasar Perairan Untuk Wisata Pantai di Pulau Samalona, Makasar, Sulawesi Selatan. Jurnal Sainsmat, 2(2):198-208.

8. Kelurahan Pulau Tidung. 2017. Laporan Tahunan 2017 Kelurahan Pulau Tidung, Kecamatan Kepulauan Seribu Selatan, Kabupaten Administrasi Kepulauan Seribu.

9. Kelurahan PulauTidung. 2018. Laporan Bulanan Januari 2018 Kelurahan Pulau Tidung, Kecamatan Kepulauan Seribu Selatan, Kabupaten Administrasi Kepulauan Seribu.

10. Khrisnamurti, H Utami, \& R Darmawan. Dampak Pariwisata Terhadap Lingkungan di Pulau Tidung Kepulauan Seribu. Jurnal Kajian, 21(3):257-273.

11. Mutmainah, H, G Kusumah, T Altanto, \& K Ondara. 2016. Kajian Kesesuaian Lingkungan Untuk Pengembangan Wisata di Pantai Ganting, Pulau Simeulue, Provinsi Aceh. Jurnal Depik, 5(1):19-23.

12. Prastowo, A. 2010. Metode Penelitian Kualitatif. Ar-Ruzz. Yogyakarta.

13. Putra, AC, S Anggoro, dan Kismartini. 2015. Strategi Pengembangan Ekowisata Melalui Kajian Ekosistem Mangrove di Pulau Pramuka, Kepulauan Seribu. Jurnal Saintek Perikanan, 10(2):91-97.

14. Supriharyono, 2016. Kondisi Terumbu Karang di Pulau Tidung, Kepulauan Seribu dan Sekitarnya. Jurnal Lingkungan dan Pembangunan, 2(1):332-346. 
15. Tambunan, JM, S Anggoro, \& H Purnaweni. 2013. Kajian Kualitas Lingkungan dan Kesesuaian Wisata Pantai Tanjung Pesona Kabupaten Bangka. Prosiding Seminar Nasional Pengelolaan Sumberdaya Alam dan Lingkungan. Magister IImu Lingkungan, Universitas Diponegoro, Semarang.

16. Wijaya P, T Putra, F Hidayat, C Levraeni, M Rizmaadi, \& Ambariyanto.2018. Suitability Analysis For Scuba Diving To Develop Marine Tourism At Saebus Island, East Java, Indonesia. E3S Web of Conferences. ICENIS 2017.

17. Yogaswara, G M, E Indrayanti, \& H Setiyono. 2016. Pola Arus Permukaan di Perairan Pulau Tidung, Kepulauan Seribu, Provinsi DKI Jakarta pada Musim Peralihan (MaretMei). Jurnal Oseanografi, 5(2):227-233.

18. Yulianda, F. 2007. Ekowisata Bahari Sebagai Alternatif Pemanfaatan Sumberdaya Pesisir Berbasis Konservasi. Unpublished Paper. Departemen Manajemen Sumberdaya Perairan, Fakultas Perikanan dan IImu Kelautan. Institut Pertanian Bogor. Bogor.

19. Yulisa, EN, Y Johan \& D Hartono. 2016. Analisis Kesesuaian dan Daya Dukung Ekowisata Pantai Kategori Rekreasi Pantai Laguna Desa Merpas Kabupaten Kaur. Jurnal Enggano, 1(1):97-111.

20. Zelenka, J, \& J Kacetl. 2014. The Concept of Carrying Capacity in Tourism. Journal Amfiteatru Economic, 16(36):641-654. 